Med. Mycol. J.

Vol. 52, $199-203,2011$

ISSN $2185-6486$

\title{
教育シリーズ : Basic mycology（2）
}

\section{Cryptococcus の菌学}

\author{
池 $\boxplus$ 玲 子
}

\author{
明治薬科大学微生物学教室
}

\section{1.はじめに}

Cryptococcus 属は担子菌類に分類され, 重篤な髄膜 忞を惹起する菌種を含んでいる. 1833 年に Kützingに より Cryptococcus mollis が記載され, The Yeasts, A Taxonomic Study の第 3 版までは本菌種が基準種で あった. 兴の後, C. neoformans が新たな基準種とし て取り扱われ，一方ではアナモルフが発見されるなど分 類と命名に変遷を重ねてきだ1).2005 年には C. neoformans のゲノムが解読され ${ }^{2}$, 分子生物学的手法も含め て研究対象の広がりと進展の速さをみせている. 本稿で は, クリプトコックス症の原因菌 Filobasidiella/Cryptococcus neoformans species complexについて, 歴 史的背景, 生活環, 遺伝型, 表層構造, 病原因子を中心 に概説する.

\section{2. 歴史的背景 ${ }^{3}$}

クリプトコックス症は, 1894-1895 年にBusse と Buschkeにより最初に記載された。肉腫様病巣に円形 ないし卵円形の細胞を観察して分離するとともに，兴の 病原性を確認した. 一方, 同年にSanfelice は, ピーチ ジュースから萊膜を有する酵母を分離し Saccharomyces neoformans と命名し, さらに類似の菌をウシ のリンパ節からも分離した. 1901 年にVuillemin によ

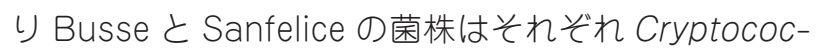
cus hominis およびC. neoformans と名付けられた. 1916 には Stoddard と Cutler が髄膜众患者より真菌を 分離 し, Torula histolyica と命名し, 1935 年に Benham は, これらの菌をC. homnis として統一して いる. 血清学的には, 1949 年に Evans がA, Bおよび Cに分類されることを報告し ${ }^{4}$, 关のおよ兴 20 年後に Wilson らにより serotype D が追加された ${ }^{5} .1950$ 年 にBenham は, 病名として cryptococcosis を提唱し, 原因菌種名をCryptococcus neoformans とした。 Vanbreusenghen と Takashio は, 1970 年に Gatti と Eeckelsにより分離された株が伸長した細胞を形成する 特徵を示すことから, これをC. neoformans var. gattii と命名し, Kwon-Chung は形態学的, 生化学的およ び血清学的性状の相違に基づき C. neoformans を C. neoformans var. neoformans ¿ C. neoformans var. gattii の 2 変種に分類した. 2011 年に出版された第 5 版The yeasts, A taxonomic Study では，兴れぞれは 別種の C. neoformans および C. gattii とされてい $る^{1,6)}$. C. neoformans は, 出芽増殖する円形から卵円 形の細胞である. しかし, Shadomy はクランプ様構造 をもつ菌糸形成を 1970 年に見出し? 1975 年に血清型 $A$ とD株各々の異なる交配型間で有性 生殖の結果, 担子胞子を形成するテレオモルフを発見 し 81976 年には血清型B と C 株についても有性生殖過 程を見出しだ. 現在は, テレオモルフは关れぞれ Filobacidiella neoformans および Filobacidiella bacillispora と命名されている1). 両菌種の比較を Table 1 にまとめて示した.

クリプトコックス症の原因菌種は, Filobasidiella neoformans/Cryptococcus neoformans-Filobasidiella bacillispora/Cryptococcus gattii complex が大部分 を占めている. Filobasidiella neoformans と Filobasidiella bacillispora はテレオモルフに, Cryptococcus neoformans と Cryptococcus gattii はアナモル フに対して命名されているが，医真菌領域では通常アナ モルフ名が使われている。この他の Cryptococcus 属 菌種が臨床材料から分離される場合があるが，兴のおよ 兴80\%は C. albidus および C. laurentii である.

\section{3. 生活環}

Cryptococcus 属菌種は出芽增殖する無性生殖過程 のみならず有性生殖環が発見された $\mathrm{a}$ と $\alpha$ 間で接合し，2核の菌系を形成して兴の先端に担 子器が生じる. 菌糸にはかすがい連結（クランプ）が認 められる, 核融合が担子器内で起こり, 減数分裂の結果 担子器の外側に交配型 $\mathrm{a}$ または $\alpha$ の担子胞子を同数形成 する (Fig. 1). 担子胞子の形態は, Filobasidiella neoformans では球形から楕円形 $(1.8-3 \times 2-5 \mu \mathrm{m})$ であるのに比して Filobasidiella bacillisporaでは桿状 $(1-1.8 \times 3-8 \mu \mathrm{m})$ である.

臨床材料也自然界から分離された株の大部分の交配型 は $\alpha て ゙ 、$ 型はきわめてまれである. したがって, 有性生 殖過程の結果もたらされる多様性の出現と自然あるいは 動物体内環境への適応に優れた株が生じる機序は謎で 


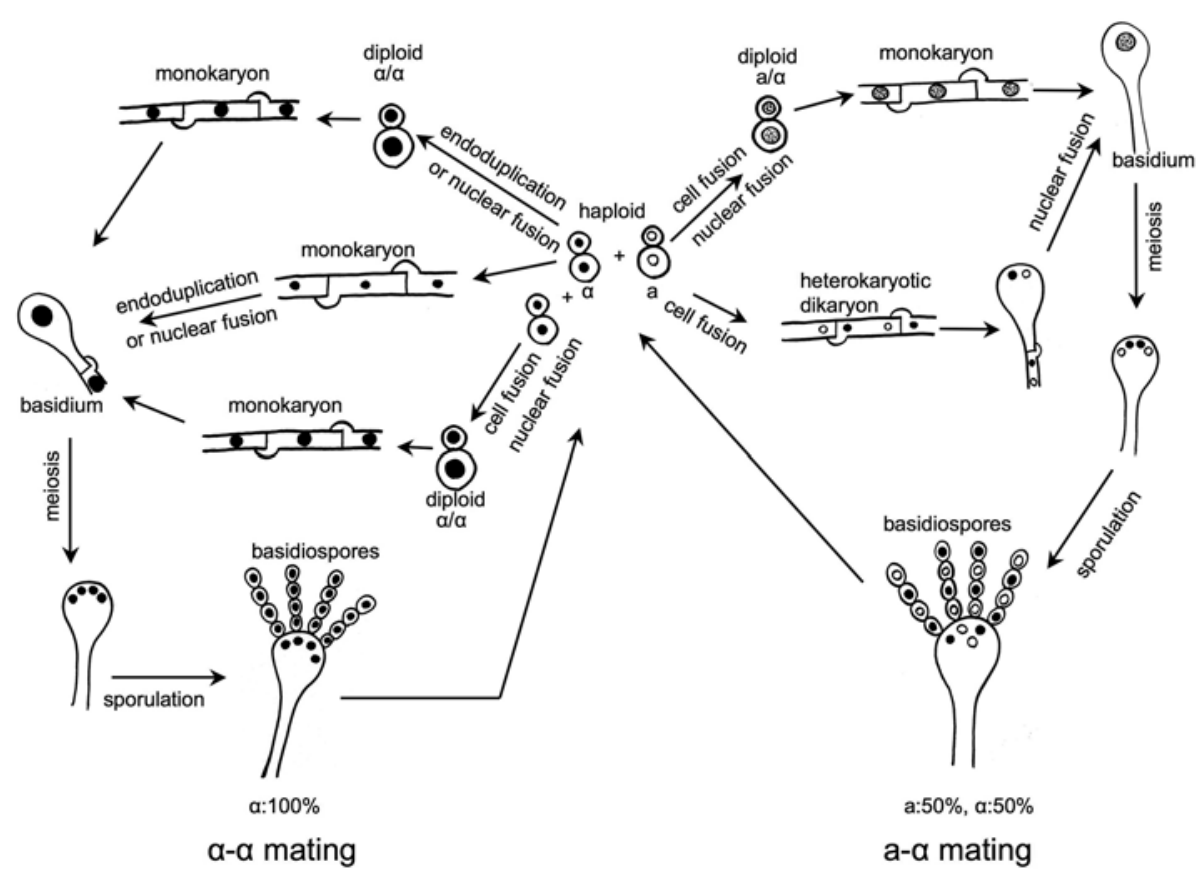

Fig. 1. Life cycle of C. neoformans.

Table 1. Comparison of features between Filobasidiella neoformans/Cryptococcus neoformans and Filobasidiella bacillispora/Cryptococcus gattii

\begin{tabular}{|c|c|c|c|c|c|}
\hline Teleomorph & \multicolumn{3}{|c|}{ Filobasidiella neoformans } & \multicolumn{2}{|c|}{ Filobasidiella bacillispora } \\
\hline Anamorph & \multicolumn{3}{|c|}{ Cryptococcus neoformans } & \multicolumn{2}{|c|}{ Cryptococcus gattii } \\
\hline $\begin{array}{l}\text { Canavanine glycine } \\
\text { bromothymol blue } \\
\text { (CGB) agar }\end{array}$ & \multicolumn{3}{|c|}{ yellow-orange } & \multicolumn{2}{|c|}{ blue/blue-green } \\
\hline $\begin{array}{l}\text { Serotype } \\
\text { (Antigenic formula) }\end{array}$ & $\begin{array}{c}A \\
(1,2,3,7)\end{array}$ & $\begin{array}{c}D \\
(1,2,3,8)\end{array}$ & $\begin{array}{l}\text { AD hybrid } \\
(1,2,3,7,8)\end{array}$ & $\begin{array}{c}\mathrm{B} \\
(1,2,4,5)\end{array}$ & $\begin{array}{c}C \\
(1,4,6)\end{array}$ \\
\hline Genotype & VNI, VNII, VNB & VNIV & VNIII & VGI, VGII, VGIII & VGIII, VGIV \\
\hline Distribution & world wide & $\begin{array}{l}\text { mainly Europe, } \\
\text { South America }\end{array}$ & & \multicolumn{2}{|c|}{ tropical, subtropical, temperate } \\
\hline Host range & \multicolumn{3}{|c|}{ immunocompromised (immunocopetent) } & \multicolumn{2}{|c|}{ immunocopetent (immunocompromised) } \\
\hline
\end{tabular}

あった.しかし, 2005 年に $\alpha$ 型株間での同一交配型によ る有性生殖過程が見いだされた ${ }^{10)}$ (Fig. 1). 1999 年以 降, バンクーバー島および北米大陸の太平洋側北西部に おける病原性の強い C. gattii の大流行 ${ }^{11.12)}$ は, $\alpha$ 型間で の交配の結果生まれた新しい株によるものとも考えられ ている.

\section{4. 遺伝型}

C. neoformans およびC. gattii 株のゲノムタイピン グについては多くの報告がなされてきたが, 2007 年に国 際的合意が得られ, multilocus sequence typing (MLST) 解析に用いる遺伝子として, CAP59, GPD1, LAC1, PLB1, SOD1, URA5 のハウスキーピング遺伝子 とIGS1の計 7つが選択された13)。この中には, 病原性
亡関係の深い CAP59 (莢膜合成), LAC1 (メラニン産 生), PLB1 (細胞侵襲) も含まれている。兴の結果, 各 菌種は兴れ炎れ 4 つの型に分類されている (Table 1).

前出の, バンクーバー島と关の付近で流行の C. gattii について，主要な株はVG\|のサブタイプVG\|la であ る. 本邦でも C. gattii VGlla が渡航歴のない患者より 分離されている(14).さらに, 新しい型の C. gattii VGIlc が米国オレゴン州で見出されおり，今後これらおよび新 たな高病原性株に対する監視がますます必要になると考 えられる.

\section{5. 表層構造}

細胞最表層に萊膜を有することが形態学的な特徵で, malt agar 上の集落は粘稠である. 萊膜は，墨汁法によ 


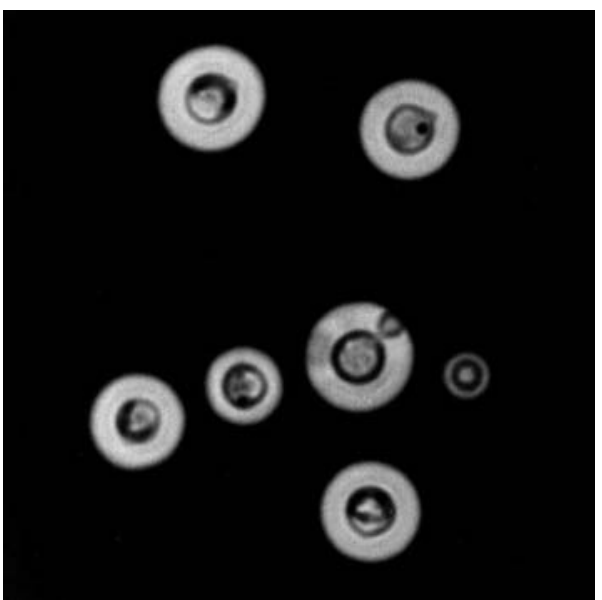

Fig. 2. C. neoformans (India ink method)

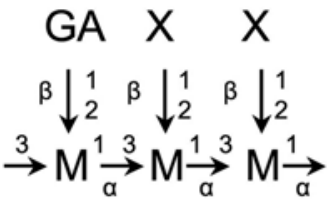

Serotype A

\section{GA $X \quad X$}

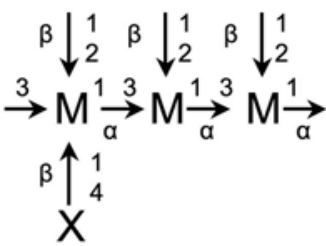

Serotype B

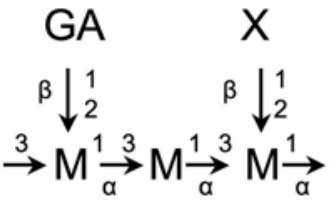

Serotype D, AD

GA $X \quad X$

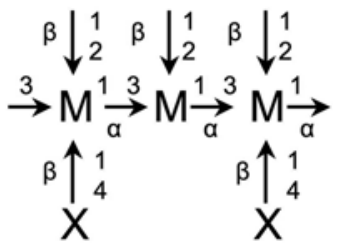

Serotype C

Fig. 3. Chemical structures of gluculonoxylomannan. GA: gluculonic acid, M: mannose, X: xylose

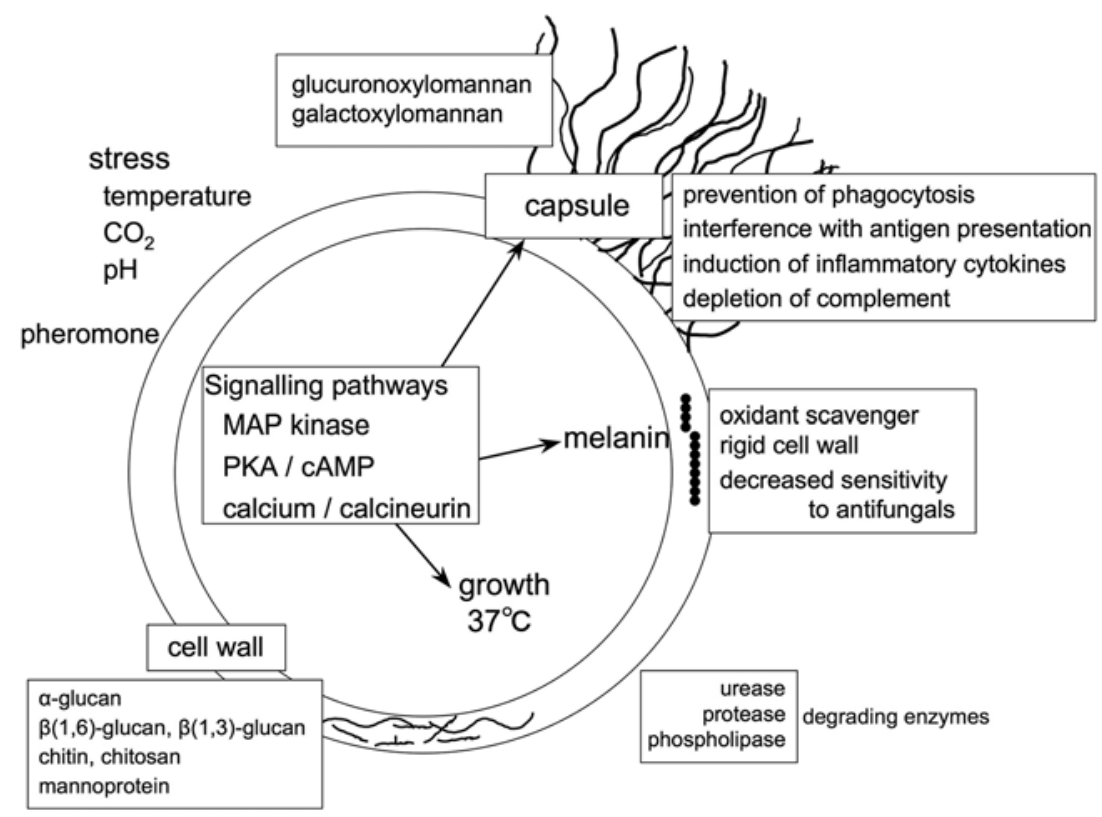

Fig. 4. Cell surface and virulence factors of $C$. neoformans.

り観察することができ (Fig. 2), クリプトコックス症の 早期診断法に利用されている。萊膜は主に酸性へテロ多 糖類のグルクロノキシロマンナンで構成され, 兴の化学 構造の相違は血清型と関連している ${ }^{15.16)}$ (Fig. 3). 莢膜 多糖類は可溶性として血清, 髄液などに検出されるため, 抗体感作ラテックス凝集反応による抗原検出法は, 特異 度と感度にすぐれた本症の迅速な血清学的診断法として 使用されている17)、細胞壁にはグルカン, キチン等の多 糖類, マンノプロテイン等のタンパク質が存在する. ま た, ジフェノール類の存在下でメラニンが合成され, Cryptococcus 細胞が褐色〜黒色細胞になるが18.19)，メ ラニンの存在部位として細胞壁が示されている（Fig. 4).

\section{6. 病原因子}

C. neoformanas は, ハトなど鳥類の粪, 土壌, 朽ち 木等から分離される.クリプトコックス症は, 白血病, がん, サルコイドーシス, リウマチなどの基礎疾患を有 する免疫不全者に多く, 1980 年代以降は AIDS 患者の死 亡原因としてランクが高い，しかし，C.gattii は，ユ一 カリの木をはじめとする複数の樹木と兴の近くの土壌か ら分離され，产のほとんどが serotype B である20). C. gattii は, 熱帯と亜熱帯地域から分離されていたが, 1999 年以降, 温带地域での C. gattii によるクリプト コックス症の報告が増加している. C. neoformans と 
比較すると免疫適格性患者での髄膜仝患者が多く AIDS 患者からの分離はむしろまれである. Serotype C 株に ついては, サハラ以南の AIDS 患者から serotype C 株 の分離が増えているとの報告がある ${ }^{21)}$.

Cryptococcus は経気道的に侵入し, 肺クリプトコッ クス症, 髄膜众および皮膚クリプトコックス症を引き起 こす，なかでも髄膜众は，治療がなされなければ致死的 転機をたどる感染症である。代表的な病原因子として古 くから $37^{\circ} \mathrm{C}$ での増殖能也萊膜が知られている。萊膜の 作用としては抗食作用性, 丁細胞への抗原提示阻止, 忿 症性サイトカイン産生抑制, 補体消費等が報告されてい る.メラニンは，細胞を強固にするとともに紫外線防御 作用がある，また，活性酸素を消去することから細胞内 殺菌抵抗性を賦与している22.23). さらに, 抗真菌薬感受 性を低下させ, 病原因子のひとつとして認識されるよう になった。

これらの病原因子の発現は複数のシグナル伝達系によ る協同作用により制御されている24)。例えば，代表的な 病原因子の萊膜は, 生体内のより高い $\mathrm{CO}_{2}$ 濃度下でプロ テインキナーゼ A/サイクリック AMP シグナル伝達系 などを介して合成が促進される。萊膜形成遺伝子の発現 は, フェロモン応答性の MAP キナーゼ経路を介しても

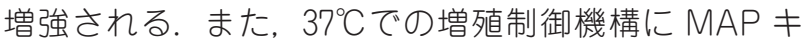
ナーゼ経路の他に $\mathrm{Ca}^{2+} /$ カルモジュリン/カルシニュー

リン経路の重要性も示されている (Fig. 4).

一方, Cryptococcus 側の因子とともに発症と病態に は宿主応答也共存する微生物がかかわってくる25). 近 年, 獲得免疫亡自然免疫の両面から解析が進行し, 受容 体認識とサイトカインの産生機序, あるいは血行性の全 身播種也血液脳関門通過機構が研究され, 感染制御に応 用が期待される知見が蓄積されつつある ${ }^{26)}$.

\section{文献}

1) Kurtzman CP, Fell JW, Boekhout T: The Yeasts, A Taxonomic Study 5th ed. Elsevier Science Publishers B.V., Amsterdam, 2011.

2) The genome of the basidiomycetous yeast and human pathogen Cryptococcus neoformans. Loftus BJ, Fung E, Roncaglia P, Rowley D. Amedeo P. Bruno D, Vamathevan J, Miranda M, Anderson IJ, Fraser JA, Allen JE, Bosdet IE, Brent MR, Chiu R. Doering TL, Donlin MJ, D'Souza CA, Fox DS, Grinberg V. Fu J, Fukushima M, Haas BJ, Huang JC, Janbon G, Jones SJ, Koo HL, Krzywinski MI, Kwon-Chung JK, Lengeler KB, Maiti R, Marra MA, Marra RE, Mathewson CA. Mitchell TG, Pertea M. Riggs FR, Salzberg SL, Schein JE, Shvartsbeyn A. Shin H. Shumway M, Specht CA, Suh BB, Tenney A, Utterback TR, Wickes BL, Wortman JR, Wye NH, Kronstad JW, Lodge JK, Heitman J, Davis RW. Fraser CM, Hyman RW: Science 307: 1321-1234, 2005.

3) Heitman J, Kozel TR, Kwon-Chung KJ, Perfect JR, Casadevall A: In Cryptococcus: From Human
Pathogen to Model Yeast. ASM Press, Washington, DC, 2011.

4) Evans EE: An immunologic comparison of twelve strains of Cryptococcus neoformans (Torula histolytica). Proc Soc Exp Biol Med 71: 644-646, 1949.

5) Wilson DE, Bennett JE, Bailey JW: Serologic grouping of Cryptococcus neoformans. Proc Soc Exp Biol Med. 127: 820-823, 1968.

6）杉田 隆, 高島昌子：病原性酵母の分類と同定における 最近の動向. Med Mycol J 52: 107-115, 2011.

7) Shadomy HJ: Clamp connections in two strains of Cryptococcus neoformans. Spectrum Monogr Ser 1: 67-72, 1970.

8) Kwon-Chung KJ: A new genus, Filobasidiella, the perfect state of Cryptococcus neoformans. Mycologia 67: 1197-1200, 1975.

9) Kwon-Chung KJ: A new species of Filobasidiella, the sexual state of Cryptococcus neoformans B and C serotypes. Mycologia 68: 943-946, 1976.

10) Fraser JA, Giles SS, Wenink EC, Geunes-Boyer SG. Wright JR, Diezmann S, Allen A, Stajich JE, Dietrich FS, Perfect JR, Heitman J: Same-sex mating and the origin of the Vancouver Island Cryptococcus gattii outbreak. Nature 437: 1360-1364. 2005.

11) Datta K, Bartlett KH, Baer R, Byrnes E, Galanis E, Heitman J, Hoang L, Leslie MJ, MacDougall L, Magill SS, Morshed MG, Marr KA: Cryptococcus gattii Working Group of the Pacific Northwest. Spread of Cryptococcus gattii into Pacific Northwest region of the United States. Emerg Infect Dis 15: 1185-1191, 2009.

12) Ma H, Hagen F, Stekel DJ, Johnston SA, Sionov E, Falk R, Polacheck I, Boekhout T, May RC: The fatal fungal outbreak on Vancouver Island is characterized by enhanced intracellular parasitism driven by mitochondrial regulation. Proc Natl Acad Sci USA 106: 12980-12985, 2009.

13) Meyer W. Aanensen DM, Boekhout T, Cogliati M, Diaz MR, Esposto MC, Fisher M, Gilgado F. Hagen F, Kaocharoen S, Litvintseva AP. Mitchell TG, Simwami SP, Trilles L, Viviani MA, Kwon-Chung J: Consensus multi-locus sequence typing scheme for Cryptococcus neoformans and Cryptococcus gattii. Med Mycol 47: 561-570, 2009.

14) Okamoto K. Hatakeyama S, Itoyama S, Nukui $Y$, Yoshino Y, Kitazawa T, Yotsuyanagi H, Ikeda R, Sugita T, Koike K: Cryptococcus gattii genotype VGlla infection in man, Japan, 2007. Emerg Infect Dis 16: 1155-1157, 2010 .

15) Bhattacharjee AK, Bennett JE, Glaudemans CP: Capsular polysaccharides of Cryptococcus neoformans. Rev Infect Dis 6: 619-624, 1984.

16) Ikeda $R$, Shinoda $T$, Fukazawa $Y$, Kaufman L: Antigenic characterization of Cryptococcus neoformans serotypes and its application to serotyping of clinical isolates. J Clin Microbiol 16: 22-29. 1982.

17）山口英世, 内田勝久, 久米光, 篠田孝子, 渡辺一功, 楠俊 雄, 比留間政太郎, 石崎宏 : 日本医真菌学会標準化委員 会報告（1992-1994 年). 真菌誌 36: 61-86, 1995.

18) Staib F: Cryptococcus neoformans und Guizotia 
abyssinica (syn. G. Oleifera D. C.). Z Hyg 148: 466-475, 1962.

19) Polacheck I, Hearing VJ, Kwon-Chung KJ: Biochemical studies of phenoloxidase and utilization of catecholamines in Cryptococcus neoformans. J Bacteriol 150: 1212-1220, 1982.

20) Ellis DH, Pfeiffer TJ: Natural habitat of Cryptococcus neoformans var. gattii. J Clin Microbiol 28: 1642-1644. 1990

21) Litvintseva AP, Thakur R, Reller LB, Mitchell TG: Prevalence of clinical isolates of Cryptococcus gattii serotype $C$ among patients with AIDS in Sub-Saharan Africa. J Infect Dis 192: 888-892, 2005.

22) Kwon-Chung KJ, Polacheck I, Popkin TJ: Melanin-lacking mutants of Cryptococcus neoformans and their virulence for mice. J Bacteriol 150: 1414-1421, 1982.

23) Jacobson ES, Emery HS: Catecholamine uptake, melanization, and oxygen toxicity in Cryptococcus neoformans. J Bacteriol 1731: 401-403, 1991.

24) Kozubowski L, Lee SC, Heitman J: Signalling pathways in the pathogenesis of Cryptococcus. Cell Microbiol 11: 370-380, 2009.

25) Ikeda R, Saito F, Matsuo M. Kurokawa K, Sekimizu K. Yamaguchi M, Kawamoto S: Contribution of the mannan backbone of cryptococcal glucuronoxylomannan and a glycolytic enzyme of Staphylococcus aureus to contact-mediated killing of Cryptococcus neoformans. J Bacteriol 189: 4815-4826, 2007.

26) Kronstad JW. Attarian R, Cadieux B, Choi J, D'Souza CA, Griffiths EJ, Geddes JM, Hu G, Jung WH, Kretschmer M. Saikia S, Wang J: Expanding fungal pathogenesis: Cryptococcus breaks out of the opportunistic box. Nat Rev Microbiol 9: 193-203, 2011. 